\title{
Effectiveness evaluation for geothermal heat recovery in closed mines of Donbas
}

\author{
Dmytro Rudakov ${ }^{1 *}$, Oleksandr Inkin ${ }^{1}$, Nataliia Dereviahina ${ }^{1}$, and Vadym Sotskov ${ }^{2}$ \\ ${ }^{1}$ Dnipro University of Technology, Department of Hydrogeology and Engineering Geology, \\ 19 Yavornytskoho Ave., 49005 Dnipro, Ukraine \\ ${ }^{2}$ Dnipro University of Technology, Department of Mining Engineering and Education, \\ 19 Yavornytskoho, 49005 Dnipro, Ukraine
}

\begin{abstract}
The study aims to develop a method of effectiveness evaluation for geothermal heat recovery in closed mines of Donbas using relations of heat transfer theory in rocks and fluids. Geothermal heat is proposed to recover using coaxial geothermal probes to be installed in flooded closed mines. As a result of evaluation and ranking, five top promising sites with the highest expected performance indicators among 27 closed mines located in Donbas have been identified. The evaluation method takes into account geological settings, mine condition, and heat exchange parameters of the probe with mine water. The locations of the most promising sites were found to correlate with the areas of higher geothermal flux and the deeper mines. The results obtained can be used in feasibility studies on installation and operation of geothermal probes in closed mines.
\end{abstract}

\section{Introduction}

Under the current trends of the global energy market and the requirements of the United Nations Climate Change Convention (Paris Agreement 2015) many coalmining countries are currently experiencing a sharp decline or shut down of coal production (Fig. 1), which is accompanied by mine closure [1,2]. Among the major European coalmining producers, Belgium was the first to close its mines by 1992, France did it in 2004, and Great Britain closed its coal mines in 2015. Since 1960 till 1980 the number of German coal mines decreased from 146 to 39; the last active mine in the country "Prosper-Haniel" in Bottrop (Ruhr Basin) has been closed in December 2018 [3 - 5].

Following the global trends, Ukraine intends to abandon thermal power generation till 2050 by increasing the share of "green" energy and gradual reducing of the coal share in the country's energy balance $[6,7]$. The concept of reforming the coalmining industry presented to the Verkhovna Rada Committee on Energy and Housing and Utilities in January 2020 [8 - 11] provides the forthcoming closure of state-owned mines. At the moment, 102 of 148 coal mines in Ukraine are state-owned, whereas 67 of them are located in the uncontrolled territory; 29 of the remaining 35 state-owned coal mines in the controlled territory are planned to be closed in the near future.

\footnotetext{
* Corresponding author: rudakov.d.v@nmu.one
} 
The closure of mines is a fairly costly and capital-intensive process associated with the need to maintain the safe groundwater level in terms of prevention from waterlogging on post-mining lands, contamination of upper aquifers used for water supply, and flooding of neighbouring operated mines. In addition, a shortage of thermal energy in coalmining regions, emerged due to mine closure, makes it relevant to search for alternative energy sources and the opportunities for the optimal use of residual and renewable resources of mines after shut down [12-14].

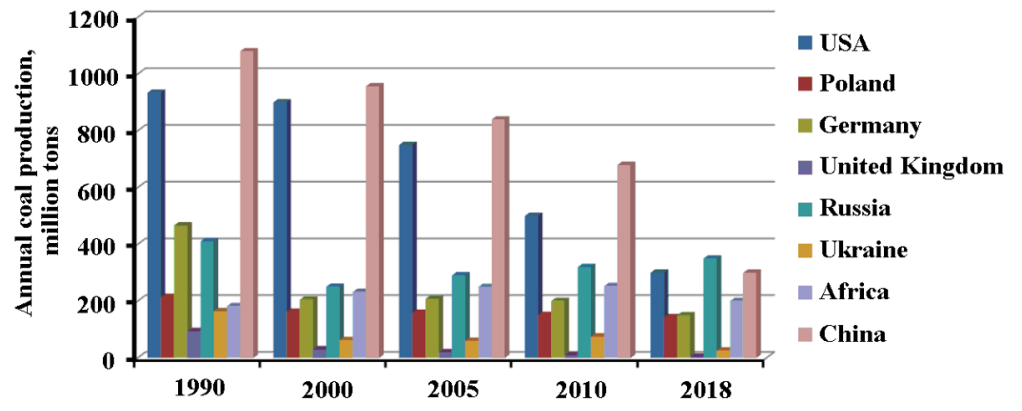

Fig. 1. Coal production in major coal-producing countries.

Up-to-date geothermal applications in surficial layers and closed mines $[15,16]$ recover renewable thermal energy accumulated in soils, rocks, and mine water. More than a half of geothermal systems in mining industry $(57 \%)$ have been installed in coal mines $[17,18]$, which indicates their high attractiveness for the geothermal industry.

All geothermal systems are subdivided into 2 types. So-called open systems use lowgrade heat of mine water or soil/rock directly; in closed systems, the heat transfer fluid is circulating through U-shaped or coaxial geothermal probes with heat exchange to soil/rocks or mine water. The potential of open system application across Ukraine has been evaluated in [21]. On the one hand, open systems are able to recover a large amount of geothermal heat at relatively low costs, albeit they need a significant area to place heat exchangers between mine water and the heat transfer fluid $[19,20]$. On the other hand, open system application requires the installation of an additional heat exchange loop with clean water or other fluid to minimize water pollution caused by suspended particles, salts, and chemically aggressive compounds contained in mine water; this reduces the open system profitability.

Due to lower environmental impact and higher compactness, closed geothermal systems have become widespread in heat supply [20-22]. According to probe positioning, these systems are divided into horizontal and vertical ones. Horizontal probes are usually installed next to houses at a depth below the level of frozen earth, in trenches or pits. Their disadvantage is the need for a quite large area to place tubes and a relatively low heat output per a running meter. Vertical probes allow recovering the thermal energy of rocks lying deeper, which enables reaching higher heat output [23]. In addition, heat exchangers of vertical systems do not require large space for installation and do not depend on solar radiation. For these reasons, this study focuses on the evaluation of closed geothermal system performance.

At the time being, just one closed geothermal installation operates in Ukraine at the "Blahodatna" mine in Western Donbas; it takes water at a temperature of $17^{\circ} \mathrm{C}$ with the discharge of $200 \mathrm{~m}^{3} / \mathrm{h}$ [24-26]. To comparison, now in Germany there are 10 active geothermal systems processing mine water of a temperature up to $50^{\circ} \mathrm{C}$ [15]. Mine water heat recovery systems have been installed in the Netherlands, Spain, Slovenia, Bulgaria and the UK. The coefficient of performance $(C O P)$ of heat pumps varies from 2.5 to 7 depending on the mine water temperature. The wide range of $C O P$ indicates the potentially high 
profitability of closed geothermal systems and the need for their further optimization that can be done by varying heat pump parameters taking into account local geothermal conditions and available infrastructure of closed mines, particularly, methane drainage boreholes. In this concern, the study aims to develop a method for evaluating the potential sites for mine water heat recovery within a large coalmining region to identify the most promising locations. Regarding to geothermal and geotechnical conditions of the Donetsk coal basin, we examined 27 closed mines in terms of potential application of geothermal probes.

\section{Geothermal heat recovery designs in closed mines}

The common practice of mine closure that can last for decades, includes three methods of shut down [27-29]; they are 1) complete flooding with suspension of water hoisting; 2) maintaining mine drainage (so-called "dry" conservation), and 3) combined method, when the mine water level in the shaft is maintained at a certain position usually higher than the deepest mine working. The first method implies backfilling the shafts and other mine workings connected to the ground surface, as well as the installation of reinforced concrete floors. Mine water level rebound after shut down of mine drainage causes the flooding of a part of underground mine workings and watering the aquifers drained before and during active mining. "Dry" conservation allows preventing from possible flooding of neighbouring active mines and waterlogging of adjusted areas. Following the combined method, the mine water level should be maintained usually $70-100 \mathrm{~m}$ below the local basis of erosion. Noncombustible materials, such as oxidation products of coal-bearing rocks (mudstones and siltstones) or sand and gravel mixtures, are used as the backfill material.

In the process of mine closure, a part of underground mine workings may be filled either with air, water or backfilling materials. Regarding the variety of geological settings and mining conditions, two designs of geothermal heat recovery at closed mines are applied [15]. Based on the post-mining experience in Ruhr area (Germany), U-shaped geothermal probes are installed in backfilled shafts, preferably in methane drainage boreholes of small diameter. Whereas, coaxial probes are installed, as a rule, in the flooded part of shafts with thermal insulation of tubes in the backfilled zone (Fig. 2) to prevent form heat losses of a circulating fluid above the mine water level. The option of using U-shaped probes in the Donbas mines without backfilling of shafts is not yet technically possible, so this paper focuses on the potential application of coaxial probes, which, unlike U-shaped ones, can be installed in the shafts without backfilling.

The analysis of low-temperature geothermal applications in the world [30 - 32] shows that most of generated thermal energy is spent for heating buildings, baths, fish farming and greenhouse facilities, which strongly depends on seasonal temperature variations. Thus, the criterion for evaluating the geothermal probe application should take into account a certain critical temperature $T_{\min }$, defined as a minimum to turn on the heating that means the beginning of the heating season. According to regulatory requirements in Ukraine and some European countries, heating of civil and industrial facilities should begin when the average daily air temperature for several days $T_{a v}$ becomes stable below $T_{\min }=8{ }^{\circ} \mathrm{C}$. The heating season ends when the air temperature becomes higher than $T_{\min }=8^{\circ} \mathrm{C}$ for several days. Based on long-run annual average temperatures, the heating season in the Donetsk coal basin lasts 158 days starting from October 29 and ending by April 4. The rest time of the year fluid circulation in the probes should be suspended in order to allow raising the mine water temperature by the geothermal flux.

During the heating period the heat transfer fluid can either be supplied directly to the heating circuits (under floor heating, fan coil units, radiators), or, if the temperature is below $20^{\circ} \mathrm{C}$, used as a source of low-grade energy in the heat pumps. After the heating 
period, the thermal energy recovered by geothermal probes may be used for heating other facilities like greenhouses, fish farming, sports and recreation facilities, or converted into electrical energy. All geothermal applications with the probes should maximize the use of the thermal potential on the ground because unused low-grade heat in such circulation systems is irretrievably lost.

The temperature of mine water and rocks cooled by the geothermal probe during the winter season rebounds slowly. For that reason, and due to the low demand for thermal energy in summer, it is recommended to suspend fluid circulation in the geothermal probe to renew the thermal potential of mine water and rocks with the geothermal flux. The duration of a summer pause in heat transfer fluid circulation should be sufficient to restore the underground temperature to the almost initial values existing before probe operation.

\section{Evaluation method}

The first step of the method is the assessment of the geothermal gradient for a mine that can be determined by the formula:

$$
\Gamma=\frac{T_{z}-T_{n l}}{H_{z}-H_{n l}}=\frac{q}{\lambda_{r}},
$$

where $T_{z}$ is the temperature of rocks at a depth $H_{z}, T_{n l}, H_{n l}$ are the temperature and depth of the neutral layer; $q$ is the geothermal flux; $\lambda_{r}$ the rock thermal conductivity.

The probe performance indicators are calculated under the following assumptions: 1) the heat transfer fluid temperature remains constant in the submerged part of the probe, 2 ) thermal resistance of the probe outer wall is low. Then, based on heat transfer equations [35 - 37], the total heat flux taken in the submerged part of the coaxial geothermal probe of a cross-section shown in Fig. 3 can be expressed as:

$$
q_{\Sigma}=\int_{H_{m w}-H_{w}}^{H_{m w}} q_{e x t}(z) d z
$$

here $H_{m w}$ is the mine water level; $H_{w}$ the length of the submerged part of the probe; $q_{e x t}(z)$ the heat flux per running meter of the probe (specific heat flux) at the depth $z$ :

$$
q_{\text {ext }}(z)=\frac{T_{\text {nat }}(z)-T_{0}}{R_{2}+R_{3}},
$$

$T_{\text {nat }}(z)$ the natural mine water temperature at the depth $z$ evaluated according the geothermal gradient $\Gamma$ :

$$
T_{n a t}(z)=T_{n l}+\Gamma z,
$$

$T_{0}$ the lowest temperature of the heat transfer fluid; $R_{2}$ the thermal resistance of the outer (steel) tube (see Fig. 3):

$$
R_{2}=\frac{1}{2 \lambda_{z} \pi} \ln \frac{d_{z, o u t}}{d_{z, \text { int }}}
$$

$R_{3}$ the thermal resistance of mine water:

$$
R_{3}=\frac{1}{2 \lambda_{w} \pi} \ln \left[\frac{2 y_{0}}{d_{z, \text { out }}}+\sqrt{\left(\frac{2 y_{0}}{d_{z, \text { out }}}\right)^{2}-1},\right.
$$


where $\lambda_{z}$ the steel tube thermal conductivity; $d_{z, \text { out }}, d_{z, \text { int }}$ are the outer and inner tube diameters, respectively; $\lambda_{w}$ is the water thermal conductivity; $y_{0}$ the distance from the tube axis to the outer contour of the shaft.

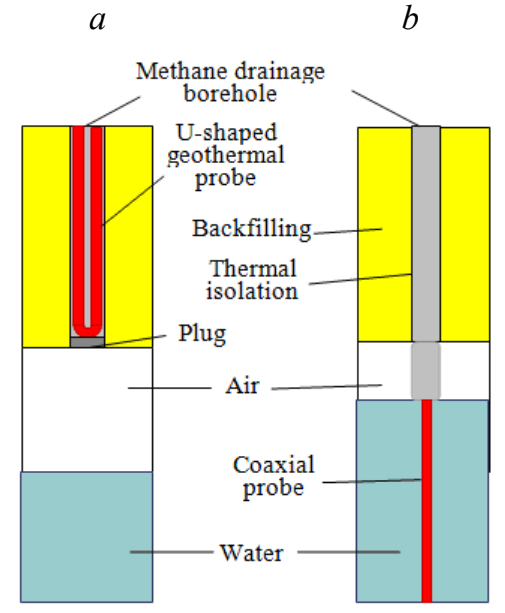

Fig. 2. Installation designs of U-shaped (a) and coaxial (b) geothermal probes in the closed mine [15].

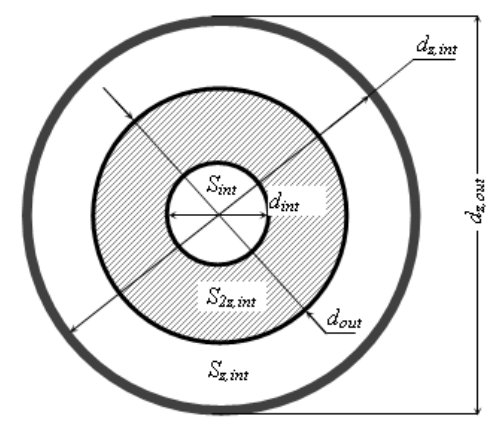

Fig. 3. Cross section of a coaxial probe. Thermal insulation is shown as hatched area; notations see in text below.

The heat transfer fluid temperature at the probe outlet on the ground is calculated as:

$$
T_{2}=\left(\frac{q_{\Sigma}}{Q C_{f} \rho_{f}}\right)+T_{0},
$$

where $Q, C_{f}, \rho_{f}$ are the discharge, specific heat capacity, and density of the heat transfer fluid.

The probe performance effectiveness at different mines can be evaluated and ranked by different indices. The first specific parameter is the average heat recovery per a running meter of the probe calculated as:

$$
q_{\Sigma s}=\frac{q_{\Sigma}}{H_{w}} .
$$

The performance effectiveness of geothermal probe connected to the heat pump loop is evaluated by the coefficient of performance $C O P$ as the key and common criterion:

$$
C O P=h \frac{T_{1}}{T_{1}-T_{2}},
$$

where $h$ is the coefficient of heat pump efficiency; $T_{1}$ the temperature in the heated building, $T_{2}$ the temperature of the fluid in the probe after gaining heat underground.

In the practice of heat exchanger operation, the probe performance effectiveness is also evaluated by the coefficient of thermal and hydrodynamic efficiency $E$ calculated as:

$$
E=q_{\Sigma} / Q \Delta P,
$$

where $\Delta P$ is the hydrodynamic resistance to the moving heat transfer fluid evaluated as follows: 


$$
\Delta P=\rho_{f} g H_{z},
$$

where $H_{z}$ is the pressure losses in the probe tubes calculated as:

$$
H_{z}=H_{z 1}+H_{z 2}, H_{z 1}=\frac{4 \chi_{z 1} H_{w}}{d_{z, \text { int }}-d_{\text {out }}} \cdot \frac{v_{f 1}^{2}}{2 g}, H_{z 2}=\frac{\chi_{z 2}\left(H_{w}+H_{m w}\right)}{d_{\text {int }}} \cdot \frac{v_{f 2}^{2}}{2 g},
$$

where $d_{\text {out }}, d_{\text {int }}$ the outer and inner diameters of the inner thermally insulated tube of the probe (see Fig. 3); $\chi_{z}$ the friction coefficient for flow inside the inner and outer tubes:

$$
\chi_{z 1}=\frac{0,309}{\left[\lg \left(\operatorname{Re}_{1} / 7\right)\right]^{2}}, \chi_{z 2}=\frac{0,309}{\left[\lg \left(\operatorname{Re}_{2} / 7\right)\right]^{2}} .
$$

The flow velocity in the probe needed to estimate the Reynolds numbers in Eq. 12 is calculated by the following equations:

$$
\begin{gathered}
v_{f 1}=\frac{Q}{S_{z, \text { int }}}, v_{f 2}=\frac{Q}{S_{\text {int }}}, \\
S_{z, \text { int }}=S_{1 z, \text { int }}-S_{2 z, \text { int }}, S_{1 z, \text { int }}=\frac{\pi d_{z, \text { int }}^{2}}{4}, S_{2 z, \text { int }}=\frac{\pi d_{\text {out }}^{2}}{4}, S_{\text {int }}=\frac{\pi d_{\text {int }}^{2}}{4} .
\end{gathered}
$$

The Reynolds numbers for the flow in the outer and inner tubes can be calculated as

$$
\operatorname{Re}_{1}=\frac{v_{f 1}\left(d_{z, \text { int }}-d_{\text {out }}\right)}{2 v}, \operatorname{Re}_{2}=\frac{v_{f 2} d_{\text {int }}}{v},
$$

where $v_{f 1}, v_{f 2}$ are the flow velocities in the outer and inner tubes; $S_{z, \text { int }}, S_{\text {int }}$ the cross-section areas of the outer and inner tubes; $S_{1 z \text { int }}, S_{2 z, \text { int }}$ the areas of the inner cross-section of the outer tube and the outer cross-section of the inner tube; $v$ is the kinematic viscosity of the heat transfer fluid.

\section{Results and discussion}

The developed evaluation method has been applied to identify the most promising sites in Donbas by examining the closed coal mines. We collected and processed the available data on the mine water level, mining depth, geological settings, as well as the results of geothermal flux survey in this region [35] (Fig. 4). The key performance parameters such as efficiency factor, the coefficient of thermal and hydrodynamic efficiency, and COP have been calculated for each site. In this study, the mines have been ranked according to the key parameter $C O P$ calculated by Eq. 9; the dimensionless parameter $E$ was considered as the supplementary criterion to take into account operational expenses.

The performance indicators have been calculated for the following values of input parameters: $T_{n l}=10^{\circ} \mathrm{C} ; T_{0}=6{ }^{\circ} \mathrm{C} ; \lambda_{z}=15 \mathrm{~W} /\left(\mathrm{m}^{\circ} \mathrm{C}\right) ; \lambda_{w}=0,65 \mathrm{~W} /\left(\mathrm{m}^{\circ} \mathrm{C}\right) ; d_{z, \text { out }}=0.114 \mathrm{~m}$; $d_{z, \text { int }}=0.1 \mathrm{~m} ; d_{\text {int }}=0,08 \mathrm{~m} ; d_{\text {out }}=0.035 \mathrm{~m} ; C_{f}=3800 \mathrm{~J} / \mathrm{kg}{ }^{\circ} \mathrm{C} ; \rho_{f}=1030 \mathrm{~kg} / \mathrm{m}^{3} ; T_{1}=50{ }^{\circ} \mathrm{C}$; $h=0.5 ; Q=5.55 \cdot 10^{-4} \mathrm{~m}^{3} / \mathrm{s}$. As a heat transfer fluid we suggested the $34 \%$ water solution of ethylene glycol. Table 1 presents the initial data and evaluation results for five top most promising sites in Donbas in terms of installation and operations of low-temperature geothermal systems to recover mine water heat. The identified mines are shown by circles in Fig. 4 whereas criss-crosses denote other examined mines. 
Table 1. Evaluated performance indicators of a geothermal coaxial probe at five top promising mining sites in the Donetsk coal basin. Here $H_{m}, H_{m w}$ are the depth of the mine and the mine water level, respectively; $H_{w}$ is the thickness of the flooded zone.

\begin{tabular}{|c|c|c|c|c|c|c|c|c|c|c|c|}
\hline No. & Mine & $\begin{array}{c}\Gamma, \\
{ }^{\circ} \mathrm{C} / \mathrm{m}\end{array}$ & $\begin{array}{c}H_{m} \\
\mathrm{~m}\end{array}$ & $\begin{array}{c}H_{m w}, \\
\mathrm{~m}\end{array}$ & $\begin{array}{c}H_{w}, \\
\mathrm{~m}\end{array}$ & $\begin{array}{l}q_{\Sigma, s}, \\
\mathrm{~W} / \mathrm{m}\end{array}$ & $\begin{array}{c}q_{\Sigma} \\
\mathrm{kW}\end{array}$ & $\begin{array}{l}T_{2} \\
{ }^{\circ} \mathrm{C}\end{array}$ & $E$ & $\eta$ & $C O P$ \\
\hline 1 & "Lenina" & 0.0333 & 1190 & 474 & 716 & 55.12 & 39.47 & 24.1 & 210.29 & 0.592 & 6.25 \\
\hline 2 & "Artioma" & 0.0278 & 1200 & 270 & 930 & 42.48 & 39.51 & 24.2 & 181.97 & 0.592 & 6.25 \\
\hline 3 & "Haievoho" & 0.0390 & 1095 & 439 & 656 & 58.96 & 38.68 & 23.8 & 223.70 & 0.592 & 6.16 \\
\hline 4 & $\begin{array}{c}\text { Named after } \\
60 \text { rokiv Radianskoi } \\
\text { Ukrainy }\end{array}$ & 0.0361 & 1018 & 120 & 898 & 42.67 & 38.32 & 23.6 & 193.11 & 0.592 & 6.12 \\
\hline 5 & "Haharina" & 0.0361 & 948 & 251 & 697 & 44.58 & 31.08 & 20.3 & 186.81 & 0.592 & 5.43 \\
\hline
\end{tabular}

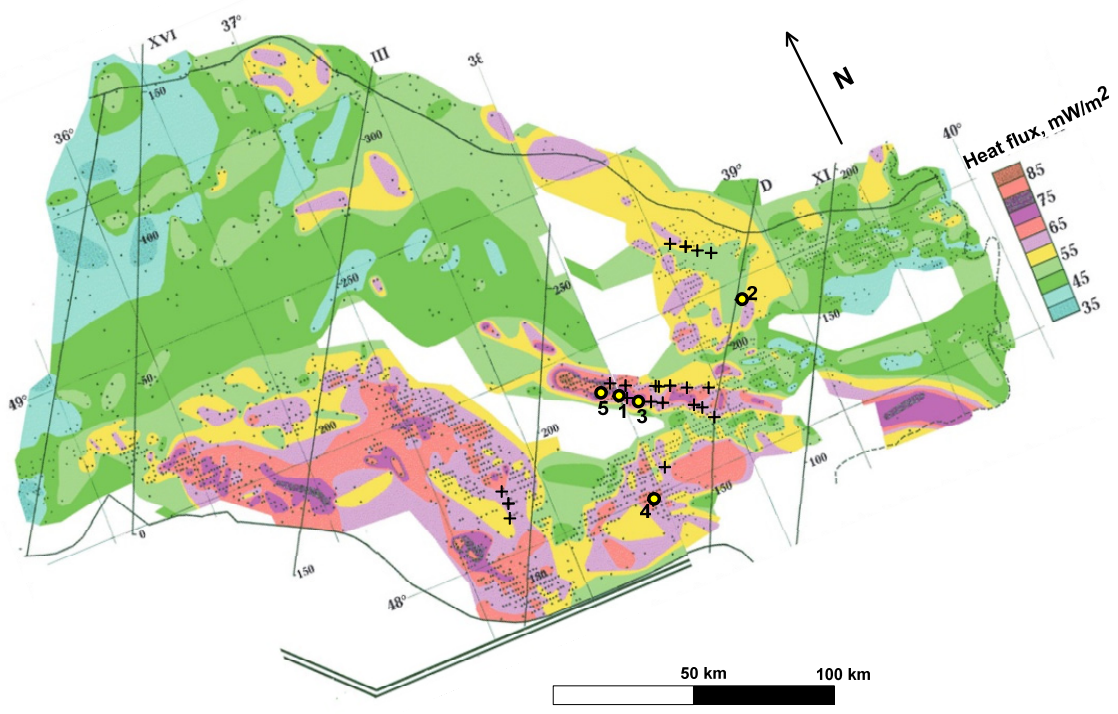

Fig. 4. Map of deep geothermal flux combined with the locations of 27 closed mines (criss-crosses) in the Donetsk coal basin. Five identified top promising mining sites are shown as circles with a yellow centre; enumeration of mines is the same as in Table 1.

The expected total heat flux that can be recovered at the identified promising sites by the coaxial probe varies from 31.1 to $39.5 \mathrm{~kW}$ at the heat output of $42.7-59.0 \mathrm{~W} / \mathrm{m}$ and $C O P$ of heat pumps of $5.43-6.25$. The performance efficiency has been determined with an increase in the length of the submerged part of the probe. As seen in Fig. 4, the selected sites correlate with the areas of elevated geothermal flux; at the same time, the coefficient of thermal and hydrodynamic efficiency $E$ and $C O P$ depend on multiple parameters and do not have clear patterns, thus, should be studied in more details for each individual site in feasibility studies.

\section{Conclusions}

A method to evaluate the effectiveness of geothermal heat recovery by coaxial probes in the watered zone of a closed flooded mine has been developed based on the equations of heat transfer in rocks and fluids. The evaluation method has been applied to rank 27 examined closed coal mines in Donbas in terms of geothermal heat recovery and identify top promising mining sites. The calculations allowed evaluating the key efficiency indicators of 
geothermal system performance including $C O P$ as the primary criterion and the coefficient of thermal and hydrodynamic efficiency of the probe as the supplementary criterion. The probe performance efficiency depends on multiple parameters, thus it does not have clear patterns and should be studied in details for each individual site.

The developed evaluation method can be further improved by taking into account the temperature changes of the heat transfer fluid in the probe inner tube and mine water, as well as by estimating the duration of the period required to restore the natural temperature of mine water after probe operation during the heating period. In addition, it is necessary to expand this approach for evaluating the performance effectiveness for U-shaped probes installed in the backfilled zone of shafts.

The developed method of geothermal heat recovery evaluation needs to be further tested and applied to other coal basins taking into account their conditions and geological settings. The obtained results may serve as the basis for developing a universal complex criterion to evaluate and optimise the probe efficiency depending on key performance parameters, including flow rate, fluid properties, probe size, seasonal changes of temperature, and energy demand by local consumers. The results obtained can be also used for feasibility studies on installation and operation of geothermal probes in closed mines.

This study was performed within the project "Possibilities of low-temperature power generation and energy storage for the valorisation of the energy use potential of mine water", which is being completed in cooperation with the Department of Applied Geology at Ruhr-University Bochum under the support of Forum Wasser und Bergbau (Germany).

\section{References}

1. Plakitkina, L.S., Plakitkin, Y.A., \& D’yachenko, K.I. (2019). Mirovye tendentsii razvitiya ugol'noy otrosli. Gornaya Promyshlennost', (1), 24-29.

2. Sadovenko, I., \& Inkin, A. (2018). Method for Stimulating Underground Coal Gasification. Journal of Mining Science, 54(3), 514-521. https://dx.doi.org/10.1134/S1062739118033941

3. Coal Atlas - Facts and figures on a fossil fuel. (2015). Heinrich Böll Foundation, Berlin, Germany, and Friends of the Earth International, London, UK.

4. Sadovenko, I., Inkin, O., \& Zagrytsenko, A. (2016). Theoretical and geotechnological fundamentals for the development of natural and man-made resources of coal deposits. Mining of Mineral Deposits, 10(4), 1-10. https://doi.org/10.15407/mining10.04.001

5. Otto, C., \& Kempka, T. (2017). Prediction of Steam Jacket Dynamics and Water Balances in Underground Coal. Gasification Energies, 10(6), 739.

6. Bondarenko, V., Kovalevs'ka, I., \& Ganushevych, K. (2014). Progressive technologies of coal, coalbed methane, and ores mining. London, United Kingdom: CRC Press, Taylor \& Francis Group. https://doi.org/10.1201/b17547

7. Bondarenko, V., Kovalevs'ka, I., Svystun, R., \& Cherednichenko, Yu. (2013). Optimal parameters of wall bolts computation in the united bearing system of extraction workings frame-bolt support. Annual Scientific-Technical Colletion - Mining of Mineral Deposits, 5-9. https://doi.org/10.1201/b16354-2

8. Khorolskyi, A., Hrinov, V., \& Kaliushenko, O. (2019). Network models for searching for optimal economic and environmental strategies for field development. Procedia Environmental Science, Engineering and Management, 6(3), 463-471.

9. Sai, K., Malanchuk, Z., Petlovanyi, M., Saik, P., \& Lozynskyi, V. (2019). Research of thermodynamic conditions for gas hydrates formation from methane in the coal mines. Solid State Phenomena, (291), 155-172. https://doi.org/10.4028/www.scientific.net/SSP.291.155

10. Khorolskyi, A., Hrinov, V., Mamaikin, O., \& Demchenko, Yu. (2019). Models and methods to make decisions while mining production scheduling. Mining of Mineral Deposits, 13(4), 53-62. https://doi.org/10.33271/mining13.04.053 
11. Golubeva, Ye. (2020). Situatsiya $v$ ugol'noy otrasli Ukrainy. Retrieved from https://112.ua/statji/orzhel-posovetoval-detyam-shahterov-ne-idti-po-stopam-roditeley-pochemuvlast-reshila-likvidirovat-shahty-522909.html

12. Sadovenko, I., Inkin, O., Dereviahina, N., \& Khryplyvets, Y. (2019). Actualization of prospects of thermal usage of groundwater of mines during liquidation. E3S Web of Conferences, (123), 01046. https://dx.doi.org/10.1051/e3sconf/201912301046

13. Bondarenko, V., Symanovych, G., \& Koval, O. (2012). The mechanism of over-coal thin-layered massif deformation of weak rocks in a longwall. Geomechanical Processes During Underground Mining, 41-44. https://doi.org/10.1201/b13157-8

14. Hordiienko, V.V, Hordiienko, I.V., \& Zavhorodnia, O.V. (2002). Teplove pole terytorii Ukrainy. Kyiv: Znannia Ukrainy, 168.

15. Potenzialstudie warmes Grubenwasser - Fachbericht 90. (2018). Landesamt für Natur, Umwelt, und Verbraucherschutz Nordrhein-Westfahlen. Recklinghausen.

16. Sadovenko, I., Rudakov, D., \& Inkin, O. (2014). Geotechnical schemes to the multi-purpose use of geothermal energy and resources of abandoned mines. Progressive Technologies of Coal, Coalbed Methane, and Ores Mining, 443-450. https://dx.doi.org/10.1201/b17547

17. Loredo, C., Roqueñí, N., \& Ordóñez, M.A. (2016). Modelling flow and heat transfer in flooded mines for geothermal energy use. International Journal of Coal Geology, (164), 115-122. https://dx.doi.org/10.1016/j.coal.2016.04.013

18. Dickinson, J.S., Buik, N., Matthews, M.C., \& Snijders, A. (2009). Aquifer thermal energy storage: theoretical and operational analysis. Géotechnique, 59(3), 249-260.

19. Rudakov, D., Sadovenko, I., Inkin, O., \& Yakubovskaya, Z. (2012). Modeling of heat transport in an aquifer during accumulation and extraction of thermal energy. Naukovyi Visnyk Natsionalnoho Hirnychoho Universytetu, (1), 40-45.

20. Snijders, A.L. (2010). Aquifer thermal energy storage in the Netherlands. Newsletter CADDET Energy Efficiency, Special Issue on the Netherlands, September.

21. Rudakov, D., \& Inkin, O. (2019). An assessment of technical and economic feasibility to install geothermal well systems across Ukraine. Geothermal Energy, 7(17). https://doi.org/10.1186/s40517-019-0134-7

22. Empfehlungen Oberflächennahe Geothermie - Planung, Bau, Betrieb und Überwachung - EA Geothermie (2015). Berlin: Ernst \& Sohn, DGG, DGGT.

23. Viessmann. Teplovye nasosnye ustanovki Vitocal 300/350. Instruktsiya po proektirovaniyu.

24. Pivnyak, G.G., Samusya, V.I., \& Oksen', Yu.I. (2017). Teoriya i praktika teplonanosnoy utilizatsii teploty shakhtnoy vody. Ugol' Ukrainy, (3), 6-10.

25. Belmas, I., Kogut, P., Kolosov, D., Samusia, V., \& Onyshchenko, S. (2019). Rigidity of elastic shell of rubber-cable belt during displacement of cables relatively to drum. International Conference Essays of Mining Science and Practice, (109), 00005. https://doi.org/10.1051/e3sconf/201910900005

26. Kovalevs'ka, I., Symanovych, G., \& Fomychov, V. (2013). Research of stress-strain state of cracked coal-containing massif near-the-working area using finite elements technique. Annual Scientific-Technical Colletion - Mining of Mineral Deposits, 159-163. https://doi.org/10.1201/b16354-28

27. Yarembasha, I.F. (2004). Tekhnologiya zakrytiya (likvidatsii) ugol'nykh shakht. Donetsk: DonNTU.

28. Sadovenko, I., Inkin, O., Yakubovskaya, Z., \& Maksimova-Gulyayeva, N. (2012). Evaluation of gas losses during storage in aquifers of the Western Doniets Basin. Naukovyi Visnyk Natsionalnoho Hirnychoho Universytetu, (6), 18-24.

29. Sadovenko, I., Rudakov, D., \& Podvigina, O. (2010). Analysis of hydrogeodynamics in a mining region during exploitation till closure of coal mines. New Techniques and Technologies in Mining School of Underground Mining, 61-69. https://doi.org/10.1201/b11329-12

30. Lund, J.W., \& Toth, A.N. (2020). Direct Utilization of Geothermal Energy 2020 Worldwide Review. In Proceedings World Geothermal Congress (pp. 1-39). Reykjavik, Iceland. 
31. Shcherbak, V.V., \& Arsenyuk, S.Yu. (2018). Analiz zahroz i ekolohichnykh ryzykiv, shcho vynykaiut vnaslidok urazhennia hirnychodobuvnykh pidpryiemstv v zoni lokalnoho viiskovoho konfliktu na skhodi Ukrainy. Zbirnyk Naukovykh Prats DonDTU, 1(47), 40-46.

32. Sadovenko I., Zahrytsenko A., Podvigina O., Dereviahina N., \& Brzeźniak S. (2018). Methodical and Applied Aspects of Hydrodynamic Modeling of Options of Mining Operation Curtailment. Solid State Phenomena, (277), 36-43. https://doi.org/10.4028/www.scientific.net/SSP.277.36.

33. Kuzmenko, O., Petlyovanyy, M., \& Heylo, A. (2014). Application of fine-grained binding materials in technology of hardening backfill construction. Progressive Technologies of Coal, Coalbed Methane, and Ores Mining, 465-469. https://doi.org/10.1201/b17547-79

34. Ulytskyi, O.A., Yermakov, V.M., Lunova, O.V., \& al. (2019). Pytannia otsinky prohnozu zmin hidroheolohichnykh umov tekhnoekosystemy Selydivskoi hrupy shakht. Ekolohichna Bezpeka ta Pryrodokorystuvannia, 4(32), 32-42.

35. Gordiyenko, V.V., Gordiyenko, I.V., \& Zavgorodnyaya, O.V. (2015). Teplovoe pole Donbassa. Geophysical Journal, 6(37), 3-23.

36. Moiseev, B.V., Zemenkov, Yu.D., Nalobin, N.V., Zemenkova, M.Yu., \& Dudin, S.M. (2016). Metody teplovogo rascheta truboprovodov razlichnogo naznacheniya. Tyumen': Tyumenskiy industrial'nyy universitet, 183.

37. Vinogradov, S.N., Tarantsev, K.V., \& Vinogradov, O.S. (2001). Vybor $i$ raschet teploobmennikov. Penzenskiy gosudarstvennyy universitet, 100. 